\title{
FAKTOR YANG MEMPENGARUHI INCOME SMOOTHING PADA PERUSAHAAN MANUFAKTUR DI BEI TAHUN 2013-2015
}

\author{
Rini Tri Hastuti \\ Fakultas Ekonomi Universitas Tarumanagara Jakarta \\ Email: rinih@fe.untar.ac.id
}

\begin{abstract}
The purpose of this research is to reexamine the factors allegedly effect toincome smoothing, whiches firm size, profitability, financial leverage, institutional ownership. The sample of this study consisted of 59 manufacturing companies listed on the Indonesia Stock Exchange (IDX) in 2013 until 2015. To determine the status of grading company and not a profit grader used Eckel index. As for answering research hypothesis used Logistic Regression analysis tools. The results of this study concludes that income smoothing taken by the company to go public in the Indonesia Stock Exchange (IDX). Multivariate testing using the Logistic Regression showed thatfirm size, profitability, financial leverage has significant effect on income smoothing. While, the variable institutional ownership had no significant effect on income smoothing.
\end{abstract}

Keywords: Firm Size, Profitability, Financial Leverage, Institutional Ownership, Income Smoothing.

\begin{abstract}
Abstrak: Tujuan penelitian ini adalah untuk menguji kembali faktor-faktor yang diduga berpengaruh terhadap tindakan perataan laba (income smoothing), yaitu firm size, profitability, financial leverage, institutional ownership. Sampel penelitian terdiri dari 59 perusahaan manufaktur yang terdaftar di Bursa Efek Indonesia (BEI) tahun 2013-2015. Untuk menentukan status perusahaan perata dan bukan perata laba digunakan indeks Eckel. Sedangkan untuk menjawab hipotesis penelitian digunakan alat analisis Logistic Regression. Penelitian ini menyimpulkan adanya tindakan perataan laba (income smoothing) yang dilakukan oleh perusahaan go public di Bursa Efek Indonesia (BEI).Pengujian multivariate dengan menggunakan Logistic Regression menunjukkan bahwa variabel firm size, profitability, financial leveragememiliki pengaruh terhadap praktik perataan laba(income smoothing). Sebaliknya, variabel institutional ownership tidak memiliki pengaruh terhadap praktik perataan laba(income smoothing).
\end{abstract}

Kata kunci: Ukuran Perusahaan, Profitabilitas, Leverage Keuangan, Kepemilikan Institusional, Perataan Laba

\section{PENDAHULUAN}

Saat ini perkembangan pasar modal di Indonesia semakin berkembang dengan pesat, sehingga menyebabkan banyak perusahaan dituntut untuk segera memperbaiki kinerjanya agar dapat bersaing dengan yang lain. Untuk dapat lebih bersaing di dunia bisnis yang semakin modern ini, perusahaan diharapkan dapat menyajikan hasil yang optimal dari kinerjanya. Hasil yang telah diperoleh perusahaan ini akan dituangkan sebagai informasi yang berguna bagi para investor dan tersaji dalam laporan keuangan.

Laporan keuangan sangat membantu untuk pengambilan keputusan bagi pihak yang berkepentingan, seperti pihak yang berada di luar maupun yang berada di dalam 
lingkungan perusahaan.Dalam laporan keuangan perusahaan yang terpenting adalah laba.Informasi laba bertujuan untuk menilai kinerja manajemen, membantu mengestimasi kemampuan laba dalam jangka panjang, dan memperkirakan risiko-risiko investasi(Pramono 2013).

Agustianto (2014) menyatakan bahwa sering kali perhatian para investor hanya terpusat pada laba saja dan membuatnya tidak memperhatikan prosedur yang digunakan untuk menghasilkan informasi laba tersebut.Hal ini menyebabkan pihak manajemen terdorong untuk melakukan tindakan disfunctional behavior (perilaku yang tidak semestinya) demi memperoleh kepentingan diri sendiri. Bentuk perilaku yang tidak semestinya yang timbul dalam hubungannya dengan laba adalah tindakan perataan laba (income smoothing).

\section{KAJIAN TEORI}

Laporan Keuangan. Menurut Ikatan Akuntan Indonesia, Pernyataan Standar Akuntansi Keuangan (2012: 1-2) menyatakan bahwa: "Laporan adalah bagian dari proses pelaporan keuangan. Laporan keuangan yang lengkap biasanya meliputi neraca, laporan laba rugi, laporan perubahan posisi keuangan (yang dapat disajikan dalam berbagai cara, misalnya sebagai laporan arus kas atau laporan arus dana), catatan dan laporan lain serta materi penjelasan yang merupakan bagian integral dari laporan keuangan."

Ikatan Akuntan Indonesia (2012:3) menjelaskan tujuan laporan keuangan adalah untuk menyediakan informasi mengenai posisi keuangan, kinerja keuangan dan arus kas entitas yang bermanfaat bagi sebagian besar kalangan pengguna laporan dalam pembuatan keputusan ekonomi.

Teori Keagenan (Agency Theory). Menurut Godfrey (2010:362) agency relationship merupakan: "As arising where there is a contract under which one party (the principal) engages another party (the agent) to perform some service on the principal's behalf. Under the contract, the principal delegates some decision making authority to the agent". Teori keagenan memberikan penjelasan mengenai hubungan antara principal dan agent suatu perusahaan yang menghasilkan publikasi atas laporan keuangan dan tahunan perusahaan. Stakeholder (principal) adalah pihak yang membutuhkan informasi mengenai kondisi keuangan perusahaan, kinerja serta informasi yang mendukung prospek perusahaan di masa yang akan datang. Manajer (agent) adalah pihak yang mengelola informasi yang dimiliki perusahaan, baik kondisi keuangan maupun non keuangan.

Perataan Laba (Income Smoothing). Widana dan Yasa (2013) mengemukakan bahwa perataan laba (income smoothing) adalah suatu tindakan dimana manajer secara sengaja mengurangi fluktuasi laba yang dilaporkan hingga mencapi tingkat laba yang diinginkan.Terdapat dua jenis perataan laba (income smoothing) menurut Rachmawati (2012): Perataan alami (Natural Smoothing) adalah perataan laba yang terjadi secara natural tanpa adanya intervensi dari pihak manapun. Perataan yang disengaja (Intentianlly Smoothing) merupakan perataan laba yang terjadi akibat adanya intervensi dari pihak lain.

Ukuran Perusahaan (Firm Size). Caecilia (2012) mendefinisikan bahwa ukuran perusahaan (firm size) adalah suatu skala di mana dapat diklasifikasikan besar kecil perusahaan menurut berbagai cara. Ada beberapa proksi yang biasanya digunakan untuk 
mewakili ukuran perusahaan yaitu jumlah karyawan, total assets, jumlah penjualan dan kapitalisasi pasar. Perusahaan yang memiliki total aktiva besar dapat mencerminkan bahwa perusahaan tersebut dapat dikategorikan sebagai perusahaan yang besar. Semakin besar ukuran sebuah perusahaan, maka akan menjadi daya tarik bagi investor untuk menanamkan modalnya.

Profitabilitas (Profitability). Menurut Kashmir dan Jakfar (2011:196) "Profitabilitas merupakan rasio untuk menilai kemampuan perusahaan dalam mencari keuntungan serta mengukur tingkat efektivitas manajemen suatu perusahaan." Menurut Rizky (2011) perusahaan cenderung meminimalisasi income saat memperoleh tingkat profitabilitas yang tinggi. Menurut Kieso (2013), penghasilan tersebut tentunya mempengaruhi kemampuan perusahaan untuk melunasi hutangnya serta meningkatkan pendanaan dalam menjalankan operasional perusahaan.

Financial Leverage. Menurut Kasmir (2009: 151) bahwa: "Rasio leverage merupakan rasio yang digunakan untuk mengukur sejauh mana aktiva perusahaan dibiayai dengan utang. Ini berarti besarnya jumlah utang yang digunakan perusahaan untuk membiayai kegiatan usahanya jika dibandingkan dengan menggunakan modal sendiri”.

Hal ini mengidentifikasikan seberapa besar tingkat resiko perusahaan yang berdampak pada performa suatu perusahaan. Diduga semakin tinggi tingkat financial leverage (DER), maka semakin besar risiko yang harus ditanggung oleh pemilik modal dan kreditur juga akan semakin meningkat.

Kepemilikan Institusional (Institutional Ownership). Menurut Gitman (2009:77) "institusional ownership is paid investment professionals to manage the finances of others." Menurut Widhianningrum (2012) "Kepemilikan institusional diukur dengan proporsi kepemilikan saham oleh pemilik institusi (bank, perusahaan asuransi, perusahaan investasi, dana pensiun, dan sebagainya)."

Hipotesis. Berdasarkan uraian di atas, maka dalam penelitian ini diperoleh beberapa hipotesis, yaitu:

Ho1: Firm sizetidak memiliki pengaruh signifikan positif terhadap perataan laba (income smoothing).

Ha1: Firm size memiliki pengaruh signifikan positif terhadap perataan laba (income smoothing).

Ho2: Profitabilitytidak memiliki pengaruh signifikan positif terhadap perataan laba (income Ha2: Profitabilitymemiliki pengaruh signifikan positif terhadap perataan laba (income smoothing).

Ho3: Financial leverage tidak memiliki pengaruh signifikan positif terhadap perataan laba (income smoothing).

Ha3: Financial leverage memiliki pengaruh signifikan positif terhadap perataan laba (income smoothing).

Ho4: Institutional Ownershiptidak memiliki pengaruh signifikan positif terhadap perataan laba (income smoothing).

Ha4: Institutional Ownershipmemiliki pengaruh signifikan positif terhadap perataan laba (income smoothing).

Kerangka pemikiran dalam penelitian ini seperti digambarkan dibawah ini: 


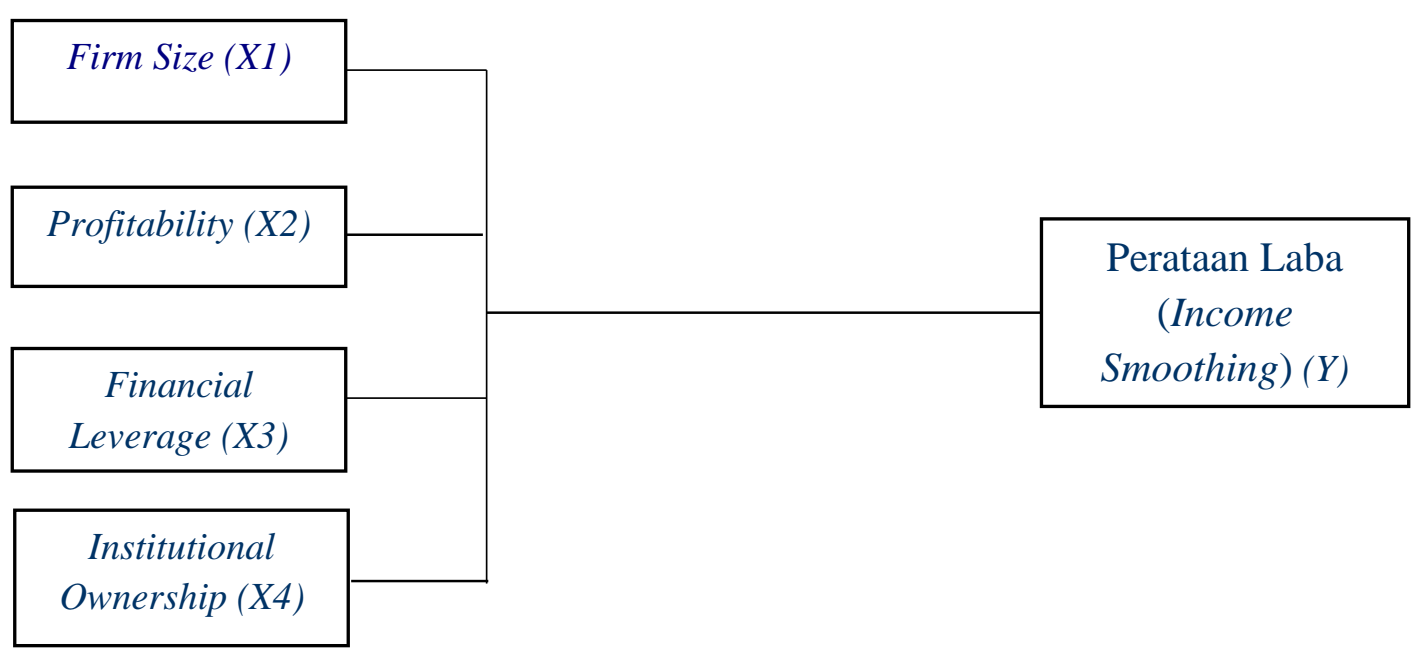

Gambar 1. Kerangka Pemikiran

\section{METODE}

Populasi, Teknik Pemilihan Sampel, dan Ukuran Sampel. Populasi penelitian ini adalah seluruh perusahaan manufaktur di Bursa Efek Indonesia (BEI) yang mengungkapkan praktik perataan laba (income smoothing). Sampel dalam penelitian ini adalah perusahaan manufaktur yang terdaftar di Bursa Efek Indonesia (BEI) pada tahun 2013-2015.Pemilihan sampel dilakukan secara purposive samplingdiyakini dapat membantu penelitian ini untuk mendapatkan informasi dari kelompok sasaran spesifik. Adapun beberapa kriteria yang digunakan dalam penelitian sampel adalah: (a) Perusahaan manufaktur yang telah terdaftar di Bursa Efek Indonesia (BEI) selama periode penelitian, yaitu tahun 2013-2015, (b) Perusahaan yang memiliki laba negatif, (c) Perusahaan tidak menggunakan tahun buku yang berakhir pada tanggal 31 Desember, (d) Perusahaan yang menggunakan mata uang USD di dalam laporan keuangannya, (e) Perusahaan manufaktur yang tidak memiliki kelengkapan variabel - variabel yang digunakan dalam penelitian. Jumlah data yang memenuhi syarat 59 perusahaan.

Variabel operasional dalam penelitian ini terdiri dari firm size, profitability, financialleverage, institutional ownership yang merupakanvariabel independent dan perataan laba (income smoothing) sebagai variabel dependent.

Perataan laba (income smoothing) dalam penelitian ini diukur dengan menggunakan indeks Eckel (1981). Eckel menggunakan Coefficient Variation (CV) variable penghasilan dan variable penjualan bersih. Rumus ini sesuai dengan penelitian yang dilakukan oleh Indarti dan Fitria (2015).

$$
\text { Indeks Eckel }=\frac{\mathrm{CV} \Delta \mathrm{I}}{\mathrm{CV} \Delta \mathrm{S}}
$$

Ukuran perusahaan (firm size) dalam penelitian ini dihitung dengan menggunakan logaritma natural dari total asset dan dirumuskan sebagai berikut.

$$
\text { Size }=\operatorname{Ln}(\text { Total Asset })
$$


Profitabilitas (profitability) dalam penelitian ini diukur dengan ROA. Rasio ini menggambarkan perbandingan antara laba bersih setelah beban bunga dan pajak dengan total aktiva perusahaan.

$$
\text { Return On Asset }=\frac{\text { Laba bersih setelah pajak }}{\text { Total Asset }}
$$

Financial leverage dalam penelitian ini, indikator yang digunakan untuk mengukur tingkat leverage adalah rasio debt to equity ratio dengan menggunakan rumus.

\section{Debt to Equity =Total Hutang \\ Total Ekuitas}

Kepemilikan institusional (institutional ownership) diukur dengan proporsi kepemilikan saham oleh pemilik institusi (bank, perusahaan asuransi, perusahaan investasi, dana pensiun, dan sebagainya).

$$
I O W N=\frac{\text { Saham yang dimiliki institusi }}{\text { Total Saham }} \quad \mathrm{X} 100 \%
$$

Hasil Uji Statistik. Analisis Statistik Deskriptif. Statistik deskriptif adalah metode yang berkaitan dengan pengumpulan dan penyajian suatu gugus data sehingga memberikan informasi yang berguna bagi penggunanya.Setelah semua data yang digunakan dalam penelitian ini diperoleh maka dilakukan analisis statistik terlebih dahulu untuk memberikan gambaran atau deskripsi suatu data pada berbagai variabel penelitian yang digunakan dalam penelitian ini. Sehingga dapat diketahui rata-rata, nilai maksimum dan minimum data serta standar deviasi dari setiap variabel yang digunakan dalam penelitian.Hasil dari analisis data untuk statistik deskriptif akan disajikan dalam table berikut.

Tabel 1. Statistik Deskriptif

\begin{tabular}{lrrrrr}
\hline & N & Minimum & Maximum & \multicolumn{1}{c}{ Mean } & Std. Deviation \\
\hline IS & 177 & .00 & 1.00 & .5593 & .49788 \\
FS & 177 & 25.619483 & 33.134053 & 28.26873784 & 1.684730931 \\
PROFIT & 177 & .000421 & .394769 & .09025816 & .080133626 \\
LEV & 177 & .137537 & 7.439847 & .90548659 & .957213455 \\
INS_OWN & 177 & .224784 & .997462 & .69583807 & .183717715 \\
Valid N & 177 & & & & \\
(listwise) & & & & &
\end{tabular}

Pengujian -2 Log likelihood Test. Pengujian ini dilakukan untuk melihat apakah model regresi yang digunakan akan menjadi baik atau tidak setelah variabel independen dimasukkan.

Tabel 2. Loq likelihood Test

\begin{tabular}{ll}
\hline Step & -2 Loglikelihood \\
Block Number $=0$ & 242.877 \\
Block Number $=1$ & 225.611 \\
\hline
\end{tabular}


Untuk melihat model regresi yang digunakan baik maka dapat diketahui dengan melihat nilai -2 Log Likelihood. Dikatakan baik, jika adanya penurunan nilai dari -2 Log Likelihood awal (block number $=0$ ) dengan -2 Log Likelihood akhir (block number $=1$ ) yang dapat ditunjukkan pada tabel di atas bahwa block number $=0$ (beginning block) mempunyai nilai sebesar 242,877 sedangkan block number $=1$ (method enter) mempunyai nilai 225,611. Dapat disimpulkan bahwa hanya konstata saja tanpa variabel bebas, nilai -2 Log Likelihood sebesar 242,877 dan setelah dimasukkan variabel bebas seperti firm size, profitability, financial leverage dan institutional ownership turun menjadi 225,611 maka model regresi ini baik untuk memprediksi pengaruh firm size, profitability, financial leverage dan institutional ownership terhadap praktik perataan laba (income smoothing).

Pengujian Nagelkerke's R square. Pengujian ini digunakan untuk melihat besarnya pengaruh yang disebabkan oleh variabel independen terhadap variabel dependen.

Tabel 3. Nagelkerke's R square

\begin{tabular}{lrrr}
\hline Step & -2 Log likelihood & Cox \& Snell R Square & Nagelkerke R Square \\
\hline 1 & $225.611^{\mathrm{a}}$ & .093 & .125 \\
\hline
\end{tabular}

Nilai Nagelkerke's R. square adalah 0,125 berarti $12,5 \%$ variasi dari praktik perataan laba (income smoothing) dapat dijelaskan oleh variabel firm size, profitability, financial leverage dan institutional ownership sedangkan sisanya $87,5 \%$ dijelaskan oleh variabel lain yang tidak dibahas.

dalam penelitian ini. Dengan nilai Nagelkerke's R square yang hanya sebesar $12,5 \%$ maka sebenarnya model regresi ini masih memiliki kekurangan. Namun model regresi ini masih dapat digunakan karena cukup dapat menjelaskan tentang variabel dependen dari penelitian ini.

Pengujian H osmer and Lemeshow's G oodness of F it Test. Pengujian ini dilakukan untuk menilai kelayakan model regresi apakah data empiris cocok atau sesuai dengan model sehingga dapat dikatakan fit. Apabila nilai signifikan $(p$-value $)>0,05$ maka model regresi cocok digunakan untuk analisa lebih lanjut karena terdapat kecocokan antara model regresi dengan data aslinya.

Tabel 4. Hosmer and Lemeshow Test

\begin{tabular}{llrrr}
\hline Step & Chi-square & df & \multicolumn{2}{c}{ Sig. } \\
\hline 1 & 12.513 & 8 & .130 \\
\hline
\end{tabular}

Pengujian Hosmer and Lemeshow's Goodness of F it Test di atas dapat dilihat bahwa nilai signifikan ( $p$-value) sebesar 0,130 atau dengan kata lain $p$-value $>0,05$ berarti terdapat kecocokan model regresi dengan data aslinya serta model regresi cocok digunakan untuk analisa lebih lanjut.

Pengujian Multivariate secara serentak. Pengujian multivariate secara keseluruhan dilakukan untuk mendapatkan hasil pengaruh dari masing-masing variabel independen terhadap variabel dependennya dengan menggunakan analisis binary logistic regression. Metode yang digunakan adalah metode enter dengan tingkat signifikansi sebesar 5\%. 
Tabel 5. Variables in the Equation

\begin{tabular}{|c|c|c|c|c|c|c|c|c|c|}
\hline & & \multirow[t]{2}{*}{ B } & \multirow[t]{2}{*}{ S.E. } & \multirow[t]{2}{*}{ Wald } & \multirow[t]{2}{*}{$\mathrm{df}$} & \multirow[t]{2}{*}{ Sig. } & \multirow[t]{2}{*}{$\operatorname{Exp}(B)$} & \multicolumn{2}{|c|}{$\begin{array}{l}\text { 95\% C.I.for } \\
\text { EXP(B) }\end{array}$} \\
\hline & & & & & & & & Lower & Upper \\
\hline \multirow{5}{*}{ Step $1^{\mathrm{a}}$} & FS & .228 & .102 & 5.008 & 1 & .025 & 1.256 & 1.029 & 1.533 \\
\hline & PROFIT & -8.598 & 2.477 & 12.047 & 1 & .001 & .000 & .000 & .024 \\
\hline & LEV & -.393 & .194 & 4.112 & 1 & .043 & .675 & .461 & .987 \\
\hline & INS_OWN & .852 & .901 & .894 & 1 & .344 & 2.345 & .401 & 13.708 \\
\hline & Constant & -5.658 & 2.991 & 3.580 & 1 & .058 & .003 & & \\
\hline
\end{tabular}

Dapat dilihat nilai signifikansi masing-masing variabel bebasnya. Untuk variabel institutional ownership nilai signifikannya sebesar 0,344 dimana lebih tinggi dari 0,05 sehingga tidak berpengaruh terhadap praktik perataan laba (income smoothing), sedangkan untuk variabel firm size, profitability dan financial leverage nilai signifikannya sebesar $0,025,0,001$, dan 0,043 dimana nilai signifikan lebih rendah dari 0,05 sehingga berpengaruh terhadap praktik perataan laba (income smoothing).

Diskusi. Berdasarkan pengujian binary logistic regression secara serentak didapatkan hasil bahwa variabel firm size berpengaruh signifikan positif terhadap praktik perataan laba (income smoothing). Variabel profitability berpengaruh signifikan positif terhadap praktik perataan laba (income smoothing). Variabel financial leverage berpengaruh signifikan positif terhadap praktik perataan laba (income smoothing). Variabel institutional ownership tidak berpengaruh signifikan terhadap praktik perataan laba (income smoothing).

\section{PENUTUP}

Penelitian ini menggunakan sampel sebanyak 59 perusahaan manufaktur yang terdaftar di Bursa Efek Indonesia selama periode 2013-2015.Dari hasil perhitungan, terdapat sebanyak 33 perusahaan yang melakukan praktik perataan laba (income smoothing) dan sebanyak 26 perusahaan yang tidak melakukan praktik perataan laba (income smoothing).Pengujian hipotesis dilakukan dengan menggunakan binary logistic regression yaitu dengan melihat nilai signifikan masing-masing variable.

Keterbatasan dari penelitian ini dikarenakan : (1) Penelitian ini hanya menggunakan perusahaan manufaktur sebagai objek penelitiannya, sehingga objek penelitian belum mencakup keseluruhan jenis perusahaan yang terdaftar di Bursa Efek Indonesia. (2) Pendeknya periode pengamatan yang dilakukan, sehingga menyebabkan tindakan praktik perataan laba (income smoothing) suatu perusahaan yang diamati kurang menggambarkan kondisi yang sebenarnya. (3) Penelitian ini hanya meneliti 4 variabel independen terhadap satu variabel dependen, yaitu firm size, profitability, financial leverage, dan institutional ownership terhadap perataan laba (income smoothing).

Penelitian ini masih jauh dari sempurna karena memiliki keterbatasan-keterbatasan. Berdasarkan pada keterbatasan tersebut, beberapa saran yang dapat diberikan untuk melakukan penelitian selanjutnya yaitu: (1) Lingkup penelitian dapat diperluas dengan tidak hanya pada perusahaan manufaktur saja, namun dapat ditambah pada perusahaan lain yang terdaftar di Bursa Efek Indonesia. (2) Penelitian selanjutnya lebih baik yaitu 
bahwa penelitian selanjutnya diharapkan menggunakan periode penelitian yang lebih panjang sehingga dapat memperoleh hasil yang lebih ideal terhadap penelitian yang dilakukan. (3) Menambah variabel lain yang mempengaruhi praktik perataan laba (income smoothing). Penggunaan variabel lain dalam penelitian selanjutnya dapat memberikan pemahaman lebih lanjut mengenai sejauh mana variabel-variabel lainnya dapat memengaruhi praktik perataan laba (income smoothing).

\section{DAFTAR RUJUKAN}

Agustianto, Rio Nur. (2014) Analisis Faktor - Faktor Yang Berpengaruh Terhadap Perataan Laba. Universitas Diponegoro

Cecilia, (2012) "Pengaruh Ukuran Perusahaan, Profitabilitas dan Leverage Operasi Terhadap Perataan Laba Pada Perusahaan Manufaktur di BEI." Jurnal Ilmiah Mahasiswa Akuntansi. 1 (4).

Gitman, Lawrence J. (2009) Principles of Managerial Finance, twelfth edition. United States: Pearson Education Addison Wesley, inc

Godfrey, Jayne M. et al. (2010) Accounting Theory. Seventh Edition. New York: John Wiley and Sons, Inc.

Ikatan Akuntansi Indonesia (2012) Standar Akuntansi Keuangan. Jakarta: Salemba Empat.

Kashmir dan Jakfar. (2011). Studi Kelayakan Bisnis. Jakarta: Kencana Prenada Media Group.

Kasmir. (2009) Analisis Laporan Keuangan. Jakarta: PT. Raja Grafindo Persada.

Pramono, Olivya. 2013 Analisis Pengaruh ROA, NPM, dan Size terhadap Praktik Perataan Laba (Studi Kasus pada Perusahaan Manufaktur yang Terdaftar di Bursa Efek Indonesia Periode 2007-2011). Jurnal Ilmiah Mahasiswa Universitas Surabaya, 2(2), 1-16.

Rahmawati. (2012) Analisis Faktor-Faktor Yang Berpengaruh Terhadap Praktik Perataan Laba (Studi Pada Perusahaan Manufaktur Yang Terdaftar Di Bei Tahun 2007 2010). Jurusan Ekonomika dan Bisnis - Universitas Diponegoro.

Rizky,Febby.2011. Analisa Faktor-Faktor yang Mempengaruhi Tindakan Perataan Laba pada Perusahaan Property and Real Estate di BEI. Jakarta: Universitas Gunadarma.

Weygandt, Jerry J., Paul D. Kimmel, Donald E. Kieso. (2013) Financial Accounting IFRS Edition: 2nd Edition. U.S.: John Wiley \& Sons, Inc.

Widana N, I Nyoman Ari dan Gerianta Wirawan Yasa. (2013) Perataan Laba Serta FaktorFaktor Yang Mempengaruhinya di Bursa Efek Indonesia. E-Jurnal Akuntansi Universitas Udayana. 3. (2), 297-317.

Widhianningrum, Purweni. (2012) Perataan Laba dan Variabel-Variabel yang Mempengaruhinya (Studi Empiris Perusahaan Manufaktur Yang Terdaftar di BEJ). Jurnal Pendidikan Akuntansi IKIP PGRI Madiun.

http://www.idx.co.id 